\title{
Effects of ozone on soil respiration rate of Siebold's beech seedlings grown under different soil nutrient conditions
}

 \\ $\left(\begin{array}{c}{ }^{a} \text { Institute of Agriculture, Tokyo University of Agriculture and Technology, Fuchu, Tokyo 183-8509, Japan } \\ { }^{b} \text { Faculty of Life and Environmental Sciences, University of Yamanashi, Kofu, Yamanashi 400-8510, Japan }\end{array}\right)$
}

\begin{abstract}
Ozone $\left(\mathrm{O}_{3}\right)$ is an air pollutant that negatively affect carbon budget in woody plants. In the present study, we aimed to clarify the effects of ozone on soil respiration rate of Siebold's beech seedlings (Fagus crenata) grown under different soil-nutrient conditions. Seedlings were grown under three levels of $\mathrm{O}_{3}$ fumigation (charcoal-filtered air or $\mathrm{O}_{3}$ at 1.0 or 1.5 times ambient concentration) in combination with three levels of nutrient supplies (non-, low- or high-fertilised) for two growing seasons. We determined soil respiration rate in July, August, September, and October of the second growing season. The seedlings were harvested to determine the dry mass in October. Significant effect of $\mathrm{O}_{3}$ on soil respiration rate was not observed in all measurements. There was a significant interaction between $\mathrm{O}_{3}$ and nutrient supply for whole-root dry mass. The dry mass in non-fertilised and low-fertilised treatments was reduced by $\mathrm{O}_{3}$, whereas $\mathrm{O}_{3}$ did not affect dry mass in the high-fertilised treatment. On the other hand, neither significant effects of $\mathrm{O}_{3}$, nor a significant interaction between $\mathrm{O}_{3}$ and nutrient supply for the biomass allocations were observed. Coefficient of positive correlation in the relation of soil respiration rate with dry mass of fine-root across the all treatments was higher than that in the relation of soil respiration rate with coarse-root and whole-root dry mass. These results indicate that no significant effect of $\mathrm{O}_{3}$ on soil respiration was mainly attributable to no response of fine root dry mass to elevated $\mathrm{O}_{3}$. Soil nutrient supply decreased soil respiration rate in August. Our results emphasize the importance of fine root in the response of soil respiration to elevated $\mathrm{O}_{3}$. To clarify the response of soil respiration to elevated $\mathrm{O}_{3}$, future researches on the effect of $\mathrm{O}_{3}$ on fine root dynamics including turnover and indirect effect on soil microbial respiration are needed.
\end{abstract}

Key words: Fine root, Ozone, Siebold's beech, Soil fertilization, Soil respiration

\section{Introduction}

Ozone $\left(\mathrm{O}_{3}\right)$ is a phytotoxic air pollutant and the concentration has been increasing over the last several decades in Japan (Matyssek and Sandermann, 2003; Akimoto et al., 2015). Many studies have demonstrated $\mathrm{O}_{3}$-induced negative impacts on tree photosynthesis and dry matter growth (Wittig et al., 2007, 2009; Watanabe et al., 2017a). Although effect of $\mathrm{O}_{3}$ on carbon budget of trees canopy was estimated based on the detailed physiological processes (Kitao et al., 2012; Watanabe et al., 2014), carbon budget in belowground is not well understood.

Soil respiration contributes greatly to the carbon budget of forest ecosystems and mainly comprises root respiration and microbial respiration; the fraction of root respiration to soil respiration is considered to be between $40 \%$ and $60 \%$ (Hanson et al., 2000). Because several papers indicated decrease of root growth and fraction of biomass allocation to roots under elevated $\mathrm{O}_{3}$ (Wittig et al., 2009; Agathokleous et al., 2016), soil respiration may decrease when $\mathrm{O}_{3}$ is elevated. Actually, $\mathrm{O}_{3}$-induced reductions in soil respiration were observed in loblolly pine (Pinus taeda) seedlings and aspen forests (Edwards, 1991; Pregitzer et al., 2006). However, the opposite response

\footnotetext{
Received; February 18, 2018

Accepted; August 19, 2018

†Corresponding Author: nab0602@cc.tuat.ac.jp

DOI: 10.2480/agrmet.D-18-00009
}

also was reported in ponderosa pine (Pinus ponderosa) seedlings, silver birch (Betula pendula) seedlings, and beech/spruce (Fagus sylvatica/Picea abies) forests (Scagel and Andersen, 1997; Kasurinen et al., 2004; Nikolova et al., 2010). Tingey et al. (2006) reported no significant effect of $\mathrm{O}_{3}$ on the soil respiration of ponderosa pine seedlings. These studies indicated that the effects of $\mathrm{O}_{3}$ on soil respiration are quite different among tree species and growing conditions.

The availabilities of nutrients vary across forested areas (e.g. Kawada, 1977; Leuschner et al., 2006). Soil-nutrient supply modifies the degree of negative impacts of $\mathrm{O}_{3}$ in both directions, i.e. enhancement and mitigation (Matyssek and Sandermann, 2003; Watanabe et al., 2017b), and therefore, soil-nutrient condition may change the effects of $\mathrm{O}_{3}$ on soil respiration rate. In fact, according to Andersen and Scagel (1997) and Scagel and Andersen (1997), increases in soil respiration rate of ponderosa pine exposed to $\mathrm{O}_{3}$ were enhanced under low-nutrient availability. However, there is no other study on the combined effects of $\mathrm{O}_{3}$ and soil-nutrient conditions on soil respiration rate.

Siebold's beech is a representative tree species native to cool-temperate forests in Japan. Based on several experimental studies carried out previously, Siebold's beech is relatively sensitive to $\mathrm{O}_{3}$ among the Japanese forest-tree species (Kohno et al., 2005; Watanabe et al., 2008; Yamaguchi et al., 2011). Kinose et al. (2017a) reported significant interactive effects of $\mathrm{O}_{3}$ and nutrient supply to soil for two growing seasons on the root and whole-plant dry mass of Siebold's beech (Fagus crenata). The 
$\mathrm{O}_{3}$-induced reduction in dry mass was observed in the non- and low-fertilised seedlings, but not in the high-fertilised seedlings. Based on this evidence, we hypothesised $\mathrm{O}_{3}$ decreased soil respiration rate under relatively poor soil-nutrient conditions (i.e. non- and low-fertilised conditions). To test this hypothesis, we investigated effects of $\mathrm{O}_{3}$ on soil respiration rate of Siebold's beech seedlings grown under different soil nutrient conditions.

\section{Materials and methods}

\subsection{Plant materials and experimental design}

Greenhouse-type $\mathrm{O}_{3}$-fumigation chambers (length: $3.6 \mathrm{~m}$, width: $2.2 \mathrm{~m}$, height in centre part: $2.0 \mathrm{~m}$ ) with a natural light source located at the Field Museum Tamakyuryo of Tokyo University of Agriculture and Technology $\left(35^{\circ} 4^{\prime} \mathrm{N}, 139^{\circ} 2^{\prime} \mathrm{E}\right.$ and $144 \mathrm{~m}$ a.s.1., Hachioji, Tokyo, Japan) were used in this study (Kinose et al., 2014). On 7 May 2014, two-year-old seedlings of Siebold's beech (Fagus crenata) were individually planted in 1/2000 a Wagner's pots (bulk: 12 L, width: 228-240 mm, depth: $259 \mathrm{~mm}$ ) filled with brown forest soil (Cambisol according to international classification system, IUSS Working Group WRB, 2015) on 7 May 2014. The soil was collected from the A-horizon of the forest floor of a deciduous forest in the Field Museum Mt. Karasawayama of Tokyo University of Agriculture and Technology (Sano, Tochigi, Japan). Before planting the seedlings, the soil was passed through a $5 \mathrm{~mm}$ sieve. The concentrations of total nitrogen and available phosphorous in the soil at initiation of the experiment were $2.4 \mathrm{~g} \mathrm{~N} \mathrm{~kg}^{-1}$ soil and $10.5 \mathrm{mg} \mathrm{P} \mathrm{kg}^{-1}$ soil, respectively (Kinose, 2017). On 15 May 2014, the seedlings were transferred into nine chambers and were grown for two growing seasons until 26 October 2015 (529 days). Mean height and stem base diameter of the seedlings at the start of experiment were $49 \mathrm{~cm}$ and $6.3 \mathrm{~mm}$, respectively. All the seedlings were regularly irrigated to keep the potted soil moist.

This experiment had a split-plot factorial design and employed the randomized block method. The whole-plot treatment consisted of three levels of $\mathrm{O}_{3}$, charcoal-filtered air (CF, mean $\mathrm{O}_{3}$ removal efficiency: ca. 60\%), 1.0 times ambient $\mathrm{O}_{3}$ concentration $\left(1.0 \times \mathrm{O}_{3}\right)$, and 1.5 times ambient $\mathrm{O}_{3}$ concentration $\left(1.5 \times \mathrm{O}_{3}\right)$, with three chamber replications, giving a total of nine chambers for data analysis. Further details of the fumigation and monitoring systems are described in Kinose et al. (2014). The gas treatment was carried out from 15 May to 30 November 2014 and from 21 April to 26 October 2015. The sub-plot treatment consisted of three levels of soil nutrient conditions. The seedlings were supplied with $500 \mathrm{ml}$ of water (NF: non-fertilised treatment), 2000-fold diluted liquid fertilizer (Hyponex 6-10-5, HYPONeX Japan Co. Ltd., Osaka, Osaka, Japan) (LF: low-fertilised treatment) or 1000-fold diluted liquid fertilizer (HF: high-fertilised treatment) to soil once every 2 weeks during the gas treatment period. Five seedlings were assigned to each $\mathrm{O}_{3}$-nutrient-chamber combination, for a total of 135 seedlings.

Table 1 shows indices of $\mathrm{O}_{3}$ fumigation in each growing season. Average $\mathrm{O}_{3}$ concentration and accumulated exposure over a threshold of $40 \mathrm{nmol} \mathrm{mol}^{-1}$ of $\mathrm{O}_{3}$ (AOT40, Agathokleous et al., 2018) for daylight hours $\left(>50 \mathrm{~W} \mathrm{~m}^{-2}\right)$ during the second growing season were $11.2 \mathrm{nmol} \mathrm{mol}^{-1}$ and $0.1 \mu \mathrm{mol} \mathrm{mol}^{-1} \mathrm{~h}$ in $\mathrm{CF}, 32.9 \mathrm{nmol} \mathrm{mol}^{-1}$ and $8.9 \mu \mathrm{mol} \mathrm{mol}^{-1} \mathrm{~h}$ in $1.0 \times \mathrm{O}_{3}$, and $49.3 \mathrm{nmol} \mathrm{mol}^{-1}$ and $26.8 \mu \mathrm{mol} \mathrm{mol}^{-1} \mathrm{~h}$ in $1.5 \times \mathrm{O}_{3}$, respectively. Air temperature and relative air humidity of one chamber in each gas treatment, totally three chambers, were continuously measured at $10 \mathrm{~min}$ intervals using a TR-72U Thermo Recorder (T\&D Corporation, Nagano, Japan). The daily average air temperature and relative air humidity measured inside the three chambers during the second growing season were $21.3^{\circ} \mathrm{C}$ and $84.5 \%$, respectively. Rotation of the pots between chambers to reduce chamber effects was carried out at three-week interval. We also conducted pot rotation within a chamber at two-week interval to reduce position effect in a chamber.

\subsection{Measurement of soil respiration rate}

We determined soil respiration rate of the potted soil where Siebold's beech seedlings were planted on 7-10 July, 4-11 August, 2-10 September and 7-13 October of the second growing season (2015). The measurements were collected five times $(2: 00,10: 00,14: 00,18: 00$ and $22: 00)$ each day. To select the seedlings for the measurement of soil respiration rate, we first determined stem basal diameter (D) and height $(\mathrm{H})$ of all seedlings on 2 June 2015, then calculated volume index $\left(D^{2} H\right)$. Three seedlings with median values of $D^{2} \mathrm{H}$ were selected to measure soil respiration rate in each $\mathrm{O}_{3}$-nutrient-chamber combination.

Dynamic closed chamber method with an acrylic plastic chamber $($ W $8 \mathrm{~cm} \times$ D $17 \mathrm{~cm} \times \mathrm{H} 11 \mathrm{~cm})$ equipped with an

Table 1. Average concentration and accumulated exposure over a threshold of $40 \mathrm{nmol} \mathrm{mol}^{-1}$ (AOT40) of ozone in each gas treatment during the period of ozone fumigation.

\begin{tabular}{llccc}
\hline & & \multicolumn{2}{c}{ Concentration $\left(\mathrm{nmol} \mathrm{mol}^{-1}\right)$} & $\begin{array}{c}\text { AOT40 }\left(\mu \mathrm{mol} \mathrm{mol}^{-1} \mathrm{~h}\right) \\
\text { Daylight hours }\end{array}$ \\
\cline { 3 - 4 } & & 24 hours & Daylight hours & $0.1(0.0)$ \\
2014 & $\mathrm{CF}$ & $8.1(1.1)$ & $13.1(1.2)$ & $4.1(0.0)$ \\
$15 \mathrm{May}-30 \mathrm{Nov}$. & $1.0 \times \mathrm{O}_{3}$ & $16.9(0.7)$ & $22.6(0.5)$ & $14.4(0.7)$ \\
2015 & $1.5 \times \mathrm{O}_{3}$ & $24.4(0.6)$ & $33.5(0.7)$ & $0.1(0.1)$ \\
21 Apr.-26 Oct. & $\mathrm{CF}$ & $8.1(0.6)$ & $11.2(1.7)$ & $8.9(0.4)$ \\
& $1.0 \times \mathrm{O}_{3}$ & $23.9(0.3)$ & $32.9(0.4)$ & $26.8(0.0)$ \\
\hline
\end{tabular}

$\mathrm{CF}$ : charcoal-filtered air, $1.0 \times \mathrm{O}_{3}: 1.0$ times ambient ozone concentration, $1.5 \times \mathrm{O}_{3}: 1.5$ times ambient ozone concentration.

Each value is the mean of three chamber replicates, and the standard deviation is shown in parenthesis.

Daylight hours: solar radiation $>50 \mathrm{~W} \mathrm{~m}^{-2}$. 
infrared gas analyser (IRGA, GMP222, Vaisala, Helsinki, Finland) was applied to determine soil respiration rate (Rochette et al., 1997). The head space of the chamber was $1.46 \mathrm{~L}$. The chambers were gently placed on the potted soil, between rim of pot and stem of seedlings, and a small amount of soil was mounted to seal the space between the chamber and the soil surface. First, we checked leaks of the chamber in each measurement by breathing outside of the chamber and confirming no change of the $\mathrm{CO}_{2}$ concentration in head space of the chamber. Then, $\mathrm{CO}_{2}$ concentration inside the chamber was monitored at one second intervals for ten minutes. After the monitoring of $\mathrm{CO}_{2}$ concentrations, soil temperature was determined using a soil conductivity and temperature tester (Soil Test HI 98331, Hanna Instruments Japan, Chiba, Japan). The linear portion of the slope of the $\mathrm{CO}_{2}$ concentration increment with time (usually from $60 \mathrm{~s}$ to $360 \mathrm{~s}$ ) was used for the calculation of soil respiration rate in a unit of $\mathrm{g} \mathrm{CO}_{2} \mathrm{~m}^{-2} \mathrm{~h}^{-1}$. To calculate the dependency of soil respiration rate to soil temperature $\left(Q_{10}\right)$, the soil respiration rate was approximated as a function of soil temperature with exponential function (Jones, 2013)

\subsection{Measurement of plant growth}

All the seedlings were harvested on 26 October 2015 to determine their biomass. We first separated the harvested seedlings into above-ground (leaf + stem) and roots. Then, the roots were separated into fine (diameter $<2 \mathrm{~mm}$ ) and coarse roots (diameter $\geq 2 \mathrm{~mm}$ ). The plant organs were dried in an oven at $80^{\circ} \mathrm{C}$ for five days and weighed.

\subsection{Statistical analysis}

Statistical analyses were undertaken using R software, version 3.4.0 ( $\mathrm{R}$ Development Core Team, 2017). The analyses were conducted using one average value per soil nutrient treatment per chamber, thus giving a total of 3 values per experimental condition. The effects of $\mathrm{O}_{3}$, nutrient supply, and soil temperature during the measurement of soil respiration rate on soil respiration rate were tested by generalized linear model (GLM). The GLM was also applied to test the effect of $\mathrm{O}_{3}$ and nutrient supply on $Q_{10}$ of soil respiration rate. Because we confirmed the normality for all parameters by Shapiro-Wilk Normality test, response variables were assumed to follow Gaussian distribution in the model. AOT 40 and amount of fertilizer until the measurement period of the second growing season were used as explanatory variables for the effects of $\mathrm{O}_{3}$ and nutrient treatments, respectively. A two-way analysis of variance (ANOVA) was applied to test the effect of $\mathrm{O}_{3}$ and nutrient supply on growth parameters of the seedlings because dry mass of whole-root and whole-plant of this study was already analysed by two-way ANOVA and published in Kinose et al. (2017a). Pearson's correlation test was used to determine the relationship between soil respiration rate in each measurement period (July, August, September and October) and dry mass of fine-root, coarse-root and whole-root of the seedlings at the end of the experiment. The mean soil respiration rate of five determinations $(2: 00$, $10: 00,14: 00,18: 00$ and $22: 00)$ was used to this analysis. We also used Pearson's correlation test for the relationship between $Q_{10}$ and AOT40.

\section{Results}

There was no significant effect of $\mathrm{O}_{3}$ on soil respiration rate in all measurement periods (Fig. 1, Table 2). Soil nutrient supply significantly decreased soil respiration rate in August. Soil respiration rate was significantly increased with increasing soil temperature. We observed significant interactions between $\mathrm{O}_{3}$ and nutrient supply, and between $\mathrm{O}_{3}$, nutrient supply and soil temperature for soil respiration in October.

There was an antagonism between $\mathrm{O}_{3}$ and nutrient supply for $Q_{10}$ of soil respiration rate in August (Fig. 2). The $Q_{10}$ was positively correlated with the amount of fertilizer in $\mathrm{CF}$ and $1.0 \times \mathrm{O}_{3}$ treatments $(r=0.715, P=0.030$ in $\mathrm{CF} ; r=0.679$, $P=0.044$ in $1.0 \times \mathrm{O}_{3}$ ), while there was no significant correlation in $1.5 \times \mathrm{O}_{3}$ treatment $(r=-0.260, P=0.499)$.

We observed significant reductions of fine-root dry mass and dry mass ratio of fine roots to coarse roots due to the soil nutrient supply, whereas the nutrient supply did not induce reductions of whole-root and whole-plant dry mass of the seedlings (Table 3, Kinose et al., 2017a). There were significant interactions between $\mathrm{O}_{3}$ and nutrient supply for whole-root dry mass and whole-plant dry mass. The dry mass in NF and LF treatments was reduced by the exposure to $\mathrm{O}_{3}$, whereas $\mathrm{O}_{3}$ did not affect dry mass in the HF treatment. The nutrient supply significantly reduced the ratios of fine-root or whole-root dry mass to whole-plant dry mass (Table 4). Neither significant effects of $\mathrm{O}_{3}$, nor a significant interaction between $\mathrm{O}_{3}$ and nutrient supply for the dry mass ratios, were observed.

As shown in Table 5, soil respiration rates in July and September were significantly and positively correlated with fine root dry mass when we analysed pooled data across gas and soil-nutrient treatments. On the other hand, there was no significant correlation between soil respiration and coarse-root or whole-root dry mass at any measurement periods.

\section{Discussion}

Soil respiration is mainly the results of root respiration (autotrophic) and processes of the microorganisms (heterotrophic) involved in the decomposition of organic materials (Cao and Woodward, 1998; Munoz et al., 2010). Soil nutrient treatment can directly affect both root and microorganisms processes. On the other hand, $\mathrm{O}_{3}$ does not physically penetrate soil (Matyssek et $a l ., 2010)$ and all the leaf litter in the present study was removed. Thus, the primary effect of $\mathrm{O}_{3}$ on soil respiration is considered as the result of the autotrophic respiration (i.e. root respiration) although there is a possibility that $\mathrm{O}_{3}$-induced changes in quantity and/or quality of root exudation affect heterotrophic respiration (Andersen, 2003).

Little effect of $\mathrm{O}_{3}$ on soil respiration rate was observed in the present study even in the NF treatment which shows relatively large reduction of root dry mass. Many papers suggested that fine root dry mass is one of the most important factors determining soil respiration (e.g. Lee and Jose, 2003; Pregitzer et al., 2008). Correlation analysis of this study also supports this suggestion (Table 5) although the biomass data was determined only in the end of growing season. The correlations of soil respiration rate with fine root dry mass of Siebold's beech seedlings were 


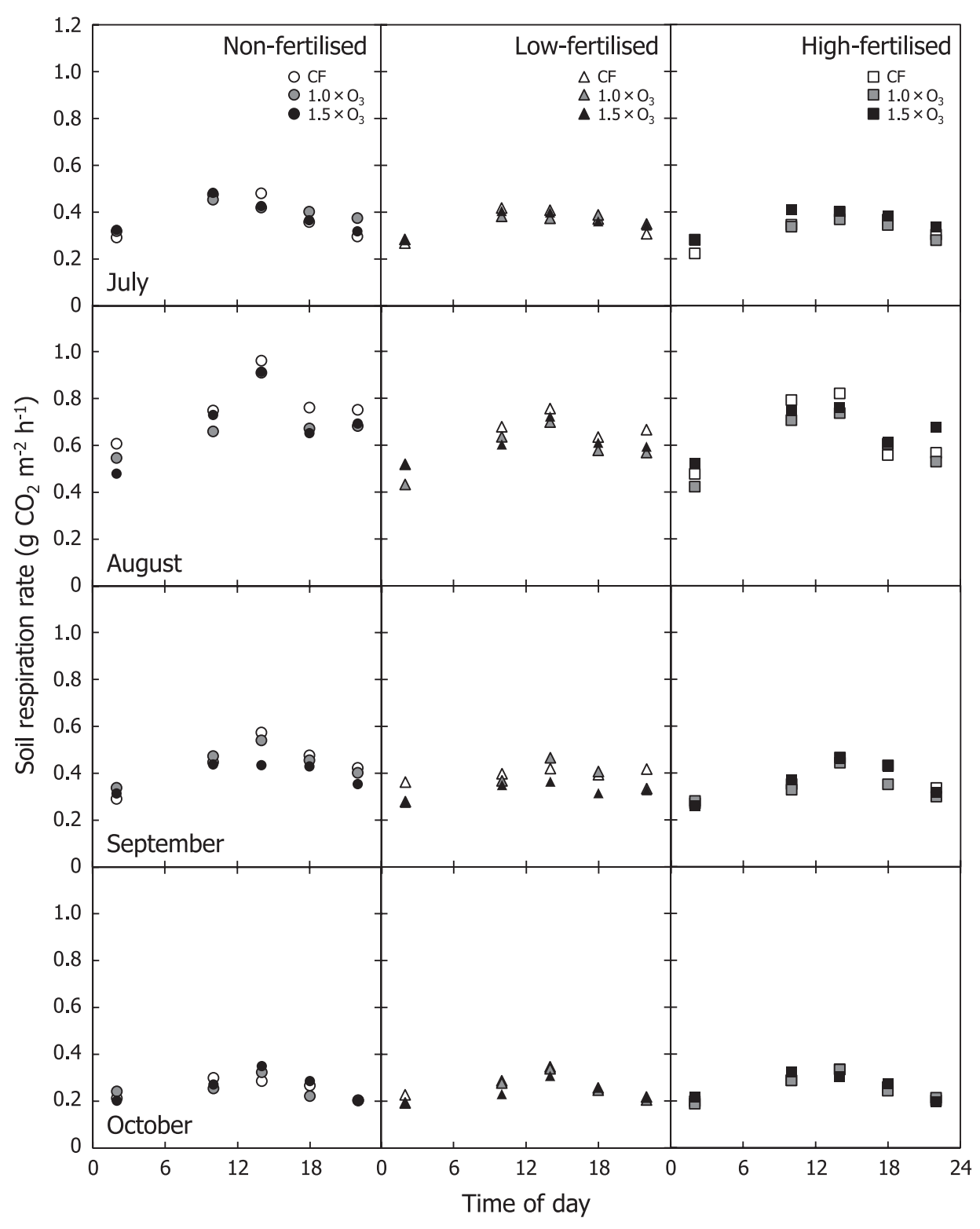

Fig. 1. Diurnal variation of soil respiration rate of Siebold's beech seedlings in July, August, September, and October 2015. The seedlings were grown under three levels of ozone fumigation in combination with three levels of nutrient supplies. CF: charcoal-filtered air, $1.0 \times \mathrm{O}_{3}: 1.0$ times ambient ozone concentration, $1.5 \times \mathrm{O}_{3}: 1.5$ times ambient ozone concentration. The result of the statistical analysis is shown in Table 2.

Table 2. Result of generalized linear model analysis for the effects of ozone, nutrient supply, and soil temperature on soil respiration rate of Siebold's beech seedlings in July, August, September, and October 2015.

\begin{tabular}{lcccc}
\hline & Jul & Aug & Sep & Oct \\
\hline Ozone $\left(\mathrm{O}_{3}\right)$ & n.s. & n.s. & n.s. & n.s. \\
Nutrient $(\mathrm{N})$ & n.s. & $*$ & n.s. & n.s. \\
Temperature $(\mathrm{T})$ & $* * *$ & $*$ & $* * *$ & $* *$ \\
$\mathrm{O}_{3} \times \mathrm{N}$ & n.s. & n.s. & n.s. & $*$ \\
$\mathrm{O}_{3} \times \mathrm{T}$ & n.s. & n.s. & n.s. & n.s. \\
$\mathrm{N} \times \mathrm{T}$ & n.s. & n.s. & n.s. & n.s. \\
$\mathrm{O}_{3} \times \mathrm{N} \times \mathrm{T}$ & n.s. & n.s. & n.s. & $*$ \\
\hline
\end{tabular}

$* P<0.05 ; * * P<0.01 ; * * * P<0.001 ;$ n.s. not significant. Actual $P$ value is shown if $0.05<P<0.10$. higher than those with coarse root and whole-root dry mass. On the other hand, neither significant effect of $\mathrm{O}_{3}$ nor significant interaction between $\mathrm{O}_{3}$ and nutrient supply for the fine root dry mass was observed (Table 3). These results indicate no effects of $\mathrm{O}_{3}$ on fine root was one of the reasons of no response of soil respiration to elevated $\mathrm{O}_{3}$.

Edwards (1991) and Nakaji and Izuta (2001) reported that $\mathrm{O}_{3}$-induced reduction of fine root dry mass was greater than that of coarse root dry mass in seedlings of loblolly pine (Pinus taeda) and Japanese red pine (Pinus densiflora), respectively, although the different responses were also observed (Agathokleous et al., 2016). The biomass of fine root is determined as a difference between growth and mortality of fine root. Matyssek et al. (2010) indicated an increased fine root turnover in mature 



Fig. 2. Temperature sensitivity $\left(Q_{10}\right)$ of soil respiration rate of Siebold's beech seedlings in July, August, September, and October 2015. CF: charcoal-filtered air, $1.0 \times \mathrm{O}_{3}: 1.0$ times ambient ozone concentration, $1.5 \times \mathrm{O}_{3}: 1.5$ times ambient ozone concentration. NF: non-fertilised, LF: low-fertilised, HF: high-fertilised. $* P<0.05, * * * P<0.001$, n.s. not significant.

Table 3. Dry mass of roots and whole plant, and dry mass ratio of fine root to coarse root (Fine/Coarse) of Siebold's beech seedlings grown under three levels of ozone fumigation in combination with three levels of nutrient supplies.

\begin{tabular}{|c|c|c|c|c|c|c|}
\hline Nutrient & Gas & Fine-root $(\mathrm{g})$ & Coarse-root $(\mathrm{g})$ & Fine/Coarse & Whole-root (g) & Whole-plant (g) \\
\hline \multirow[t]{3}{*}{ NF } & $\mathrm{CF}$ & $34.3(2.5)$ & $43.4(2.2)$ & $0.79(0.10)$ & $77.8(0.6)$ & $186.9(4.2)$ \\
\hline & $1.0 \times \mathrm{O}_{3}$ & $30.3(0.9)$ & $36.3(1.0)$ & $0.83(0.03)$ & $66.6(1.6)$ & $163.1(6.2)$ \\
\hline & $1.5 \times \mathrm{O}_{3}$ & $24.3(2.8)$ & $37.1(2.2)$ & $0.65(0.04)$ & $61.4(5.1)$ & $151.3(9.6)$ \\
\hline \multirow[t]{3}{*}{ LF } & $\mathrm{CF}$ & $30.2(6.4)$ & $43.2(3.0)$ & $0.70(0.13)$ & $73.4(8.5)$ & $189.7(14.2)$ \\
\hline & $1.0 \times \mathrm{O}_{3}$ & $30.8(6.8)$ & $42.3(2.6)$ & $0.72(0.12)$ & $73.0(9.3)$ & $183.7(8.6)$ \\
\hline & $1.5 \times \mathrm{O}_{3}$ & $26.4(8.5)$ & $36.6(3.2)$ & $0.73(0.26)$ & $63.0(8.2)$ & $171.5(17.2)$ \\
\hline \multirow[t]{3}{*}{$\mathrm{HF}$} & $\mathrm{CF}$ & $23.8(2.3)$ & $43.4(5.4)$ & $0.56(0.12)$ & $67.2(4.1)$ & $182.7(4.7)$ \\
\hline & $1.0 \times \mathrm{O}_{3}$ & $24.2(3.8)$ & $40.6(6.9)$ & $0.61(0.15)$ & $64.8(6.3)$ & $184.4(18.8)$ \\
\hline & $1.5 \times \mathrm{O}_{3}$ & $26.7(3.7)$ & $45.1(5.0)$ & $0.60(0.11)$ & $71.8(5.9)$ & $191.0(15.0)$ \\
\hline \multicolumn{7}{|c|}{ Two-way ANOVA } \\
\hline & Ozone $\left(\mathrm{O}_{3}\right)$ & n.s. & n.s. & n.s. & n.s. & n.s. \\
\hline & Nutrient $(\mathrm{N})$ & $*$ & n.s. & $*$ & n.s. & $* *$ \\
\hline & $\mathrm{O}_{3} \times \mathrm{N}$ & n.s. & n.s. & n.s. & $*$ & $*$ \\
\hline
\end{tabular}

NF: non-fertilised, LF: low-fertilised, HF: high-fertilised.

CF: charcoal-filtered air, $1.0 \times \mathrm{O}_{3}: 1.0$ times ambient ozone concentration, $1.5 \times \mathrm{O}_{3}: 1.5$ times ambient ozone concentration.

Each value is the mean of three chamber replicates, and the standard deviation is shown in parenthesis.

$* P<0.05, * * P<0.01$, n.s. not significant.

Data of whole-root day mass and whole-plant dry mass were referred Kinose et al. (2017a).

European beech exposed to elevated $\mathrm{O}_{3}$. Pregitzer et al. (2008) found that elevated ozone increased both fine root production and mortality in aspen community. The increment of root turnover would stimulate decomposition of carbohydrate from root, resulting increase of soil respiration (Matyssek et al., 2010). In the present study, however, there was no significant effect of $\mathrm{O}_{3}$ on soil respiration rate (Fig. 1, Table 2). Enhanced fine root turnover of Siebold's beech seedlings in the present study may not be a reason of no significant effect of $\mathrm{O}_{3}$ on fine root dry mass.

The $Q_{10}$ in $\mathrm{CF}$ and $1.0 \times \mathrm{O}_{3}$ were increased with increasing the amount of nutrient to the soil, while no significant correlation was observed between $Q_{10}$ and soil nutrient treatment in $1.5 \times \mathrm{O}_{3}$ treatment in August (Fig. 2). It is known that $Q_{10}$ of soil respiration responds to environmental conditions, especially temperature and soil water content (e.g. Hashimoto et al., 2009; Wang et al., 2014). However, the response of $Q_{10}$ to soil nutrient condition is not very understood. Soil respiration rates under different amount of simulated nitrogen depositions were determined in a Populus euphratica community in north-western China (He et al., 2015). However, the correlation between $Q_{10}$ of soil respiration and soil nitrogen concentration was not significant. Burton et al. (2002) measured fine root respiration and nitrogen concentration in fine root across biome in North American forests. In this study, there was also no significant correlation between $Q_{10}$ of root respiration and nitrogen concentration in root. Further research is needed to clarify the mechanism behind in the effect of soil nutrient treatment and their interaction with $\mathrm{O}_{3}$ observed in the present study.

Soil respiration rate in August decreased due to the soil nutrient supply (Fig. 1, Table 2). Nutrient supply significantly reduced fine-root dry mass, dry mass ratio of fine root to coarse root, and dry mass ratio of fine root to whole plant mass, although there was no significant effect on whole-root dry mass (Tables 3 and 4). There are several observations of decreases in fine-root biomass with increasing nitrogen availabilities in mixed-forest (Aber et al., 1985), Populus trees (Pregitzer et 
Table 4. Ratios of fine root, coarse root, and whole root dry mass to whole plant dry mass (FRMR, CRMR and RMR, respectively) of Siebold's beech seedling grown under three levels of ozone fumigation in combination with three levels of nutrient supplies.

\begin{tabular}{lllll}
\hline Nutrient & \multicolumn{1}{c}{ Gas } & FRMR & CRMR & \multicolumn{1}{c}{ RMR } \\
\hline $\mathrm{NF}$ & $\mathrm{CF}$ & $0.18(0.01)$ & $0.23(0.01)$ & $0.42(0.01)$ \\
& $1.0 \times \mathrm{O}_{3}$ & $0.19(0.01)$ & $0.22(0.00)$ & $0.41(0.01)$ \\
& $1.5 \times \mathrm{O}_{3}$ & $0.16(0.01)$ & $0.25(0.01)$ & $0.40(0.02)$ \\
$\mathrm{LF}$ & $\mathrm{CF}$ & $0.16(0.02)$ & $0.23(0.01)$ & $0.38(0.01)$ \\
& $1.0 \times \mathrm{O}_{3}$ & $0.17(0.03)$ & $0.23(0.00)$ & $0.39(0.03)$ \\
& $1.5 \times \mathrm{O}_{3}$ & $0.15(0.03)$ & $0.21(0.03)$ & $0.36(0.02)$ \\
$\mathrm{HF}$ & $\mathrm{CF}$ & $0.13(0.01)$ & $0.24(0.02)$ & $0.37(0.01)$ \\
& $1.0 \times \mathrm{O}_{3}$ & $0.13(0.02)$ & $0.22(0.02)$ & $0.35(0.00)$ \\
& $1.5 \times \mathrm{O}_{3}$ & $0.14(0.02)$ & $0.24(0.01)$ & $0.37(0.00)$ \\
\hline
\end{tabular}

Two-way ANOVA

$\begin{array}{lcll}\text { Ozone }\left(\mathrm{O}_{3}\right) & \text { n.s. } & \text { n.s. } & \text { n.s. } \\ \text { Nutrient }(\mathrm{N}) & * * & \text { n.s. } & * * * \\ \mathrm{O}_{3} \times \mathrm{N} & \text { n.s. } & \text { n.s. } & \text { n.s. }\end{array}$

NF: non-fertilised, LF: low-fertilised, HF: high-fertilised.

CF: charcoal-filtered air, $1.0 \times \mathrm{O}_{3}: 1.0$ times ambient ozone concentration, $1.5 \times \mathrm{O}_{3}: 1.5$ times ambient ozone concentration.

Each value is the mean of three chamber replicates, and the standard deviation is shown in parenthesis.

** $P<0.01, * * * P<0.001$, n.s. not significant.

al., 1995) and Japanese red pine (Pinus densiflora, Nakaji et al., 2004). We think that the reduction in soil respiration rate of Siebold's beech seedlings in our study was partly due to the reduction in fine-root biomass with high respiration activity (Makita et al., 2009; Chen et al., 2010; Burton et al., 2012).

Soil-nutrient supply may directly affect soil microbial communities, although the impact of $\mathrm{O}_{3}$ first occurs in leaves of plants as mentioned above. According to a meta-analysis on the responses of soil respiration and its components (i.e., autotrophic and heterotrophic respirations) to nitrogen addition (Zhou et $a l ., 2014)$, nitrogen addition induces decreases of heterotrophic respiration in temperate and boreal forests. Although the increase in soil nitrogen concentration in this study was relatively small, as compared to that of phosphorous and potassium concentrations (Kinose et al., 2017b), there is a possibility that not only a decrease of root respiration, but also that of microbial respiration contributed to the decrease in soil respiration rate by nutrient supply.

In the present study, the growth enhancement of Siebold's beech seedlings by soil nutrient treatment was little (Table 3). Total soil nitrogen concentration at the initiation of the experiment was $2.4 \mathrm{~g} \mathrm{~N} \mathrm{~kg}^{-1}$, and the seedlings in LF and $\mathrm{HF}$ treatments were supplied nitrogen at 198 and $396 \mathrm{mg} \mathrm{N}$ during one growing season. On the other hand, the nitrogen concentration in the initial soil and amount of nitrogen supply during one growing season in Yamaguchi et al. (2007), which demonstrated growth enhancement of Siebold's beech seedlings by the application of ammonium nitrate, were $3.5 \mathrm{~g} \mathrm{~N} \mathrm{~kg}^{-1}$ and 100 and $250 \mathrm{mg} \mathrm{N}$ per seedling. The nitrogen content and amount of nitrogen application to soil were comparable between our study and Yamaguchi et al. (2007). On the other hand, leaf
Table 5. Correlation coefficient between soil respiration rate in each month and dry mass of fine-root, coarse-root and whole-root in Siebold's beech seedling across the three levels of ozone fumigation in combination with three levels of nutrient supplies.

\begin{tabular}{lcccr}
\hline & July & August & September & October \\
\hline Fine-root & $0.475^{*}$ & 0.295 & $0.445^{*}$ & 0.155 \\
Coarse-root & -0.358 & 0.139 & 0.004 & -0.083 \\
Whole-root & 0.120 & 0.300 & 0.324 & 0.060 \\
\hline
\end{tabular}

See Materials and method for details of the analysis.

$* P<0.05$.

nitrogen content in the present study $\left(1.6-1.9 \mathrm{~g} \mathrm{~N} \mathrm{~m}^{-2}\right)$ was higher than that of Yamaguchi et al. (2007) $\left(0.8-1.3 \mathrm{~g} \mathrm{~N} \mathrm{~m}^{-2}\right)$ even in the NF treatment (Kinose et al., 2017a). This result indicates a possibility that the nutrient in the original soil of the present study was sufficient and therefore the fertilization did not affect the growth of Siebold's beech seedlings.

Root growth limitation due to the pot size is an important experimental concern when using pot-grown seedlings (e.g. Arp, 1991). We checked the ratio of root dry mass to shoot dry mass ( $\mathrm{S} / \mathrm{R}$ ratios) of the seedlings in the end of first and second growing seasons (Kinose et al., 2017a). If the size of pot was not enough for root growth, the $\mathrm{R} / \mathrm{S}$ ratios would become low in the second growing season as compared to the first growing season. However, the R/S ratios in the end of first growing season and second growing season were similar $(0.59$ and 0.63 on average of all treatments, respectively). Therefore, we consider the restriction of root growth due to the limited soil volume was not serious.

\section{Conclusion}

Based on the results obtained from this study, our hypothesis was rejected. Fine root biomass of Siebold's beech was an important factor in determining soil respiration rate under elevated $\mathrm{O}_{3}$ with various soil nutrient conditions in our experiment. On the other hand, neither significant effects of $\mathrm{O}_{3}$, nor a significant interaction between $\mathrm{O}_{3}$ and nutrient supply for fine root although significant interaction between $\mathrm{O}_{3}$ and soil nutrient treatment was observed for whole-root biomass. Our results emphasize the importance of fine root in the response of soil respiration to elevated $\mathrm{O}_{3}$. There are many reports on $\mathrm{O}_{3}$-induced reduction in fine root biomass (Edwards, 1991; Nakaji and Izuta, 2001). To clarify the response of soil respiration to elevated $\mathrm{O}_{3}$ condition, future researches on the effect of $\mathrm{O}_{3}$ on fine root dynamics including turnover and indirect effect on soil microbial respiration are needed.

\section{Acknowledgments}

The authors are greatly indebted to Dr. Kazuhide Matsuda, Mr. Hiroyuki Ozawa and Mr. Yoshinobu Fukamachi (Tokyo University of Agriculture and Technology) for the technical support. This study was supported by JSPS KAKENHI, Type B program (18H03410 to MW and TI), Young Scientists B (15K16136 to MW), and Challenging Exploratory Research (15K12217 to TI and MW). 


\section{References}

Aber JD, Melillo JM, Nadelhoffer KJ, McClaugherty CA, Pastor J, 1985: Fine root turnover in forest ecosystems in relation to quantity and form of nitrogen availability: a comparison of two methods. Oecologia 66, 317-321.

Agathokleous E, Saitanis CJ, Wang X, Watanabe M, Koike T, 2016: A review study on past 40 years of research on effects of tropospheric $\mathrm{O}_{3}$ on belowground structure, functioning, and processes of trees: a linkage with potential ecological implications. Water Air and Soil Pollution 227, 33.

Agathokleous E, Kitao M, Kinose Y, 2018: A review study on $\mathrm{O}_{3}$ phytotoxicity metrics for setting critical levels in Asia. Asian Journal of Atmospheric Environment 12, 1-16.

Akimoto H, Mori Y, Sasaki K, Nakanishi H, Ohizumi T, Itano Y, 2015: Analysis of monitoring data of ground-level ozone in Japan for long-term trend during 1990-2010: causes of temporal and spatial variation. Atmospheric Environment 102, 302-310.

Andersen CP, 2003: Source-sink balance and carbon allocation below ground in plants exposed to ozone. New Phytologist 157, 213-228.

Andersen CP, Scagel CF, 1997: Nutrient availability alters belowground respiration of ozone-exposed ponderosa pine. Tree Physiology 17, 377-387.

Arp WJ, 1991: Effects of source-sink relations on photosynthetic acclimation to elevated $\mathrm{CO}_{2}$. Plant, Cell \& Environment 14, 869-875.

Burton AJ, Pregitzer KS, Ruess RW, Hendrick RL, Allen MF, 2002: Root respiration in North American forests: effects of nitrogen concentration and temperature across biomes. Oecologia 131, 559-568.

Burton AJ, Jarvey JC, Jarvi MP, Zak DR, Pregitzer KS, 2012: Chronic N deposition alters root respiration-tissue $\mathrm{N}$ relationship in northern hardwood forests. Global Change Biology 18, 258-266.

Cao M, Woodward FI, 1998: Dynamic responses of terrestrial ecosystem carbon cycling to global climate change. Nature 393, 249-252.

Chen DM, Zhou LX, Rao XQ, Lin YB, Fu SL, 2010: Effects of root diameter and root nitrogen concentration on in situ root respiration among different seasons and tree species. Ecological Research 25, 983-993.

Edwards NT, 1991: Root and soil respiration responses to ozone in Pinus taeda L. seedlings. New Phytologist 118, 315-321.

Hanson PJ, Edwards NT, Garten CT, Andrews JA, 2000: Separating root and soil microbial contributions to soil respiration: a review of methods and observations. Biogeochemistry 48, 115-146.

Hashimoto T, Miura S, Ishizuka S, 2009: Temperature controls temporal variation in soil $\mathrm{CO}_{2}$ efflux in a secondary beech forest in Appi Highlands, Japan. Journal of Forest Research 14, 44-50.

He X, Lv G, Qin L, Chang S, Yang M, Yang J, Yang X, 2015: Effects of simulated nitrogen deposition on soil respiration in a Populus euphratica community in the Ebinur Lake area, a desert ecosystem of Northwestern China. PLoS ONE 10, e0137827.

IUSS Working Group WRB, 2015: World Reference Base for Soil Resources 2014, Update 2015. International Soil Classification System for Naming Soils and Creating
Legends for Soil Maps. World Soil Resources Reports No. 106. FAO, Rome, pp. 192. [online 15 January 2018] URL: http://www.fao.org/3/a-i3794e.pdf

Jones HG, 2013: Plants and Microclimate: A Quantitative Approach to Environmental Plant Physiology, 3rd edition, Cambridge University Press, Cambridge, pp. 407.

Kasurinen A, Kokko-Gonzales P, Riikonen J, Vapaavuori E, Holopainen T, 2004: Soil $\mathrm{CO}_{2}$ efflux of two silver birch clones exposed to elevated $\mathrm{CO}_{2}$ and $\mathrm{O}_{3}$ levels during three growing seasons. Global Change Biology 10, 1654-1665.

Kawada H, 1977: Nitrogen forms of representative Japanese forest soils. Bulletin of the Government Forest Experiment Station 297, 105-131. (In Japanese)

Kinose Y, Azuchi F, Uehara Y, Kanomata T, Kobayashi A, Yamaguchi M, Izuta T, 2014: Modeling of stomatal conductance to estimate stomatal ozone uptake by Fagus crenata, Quercus serrata, Quercus mongolica var. crispula and Betula platyphylla. Environmental Pollution 194, 235-245.

Kinose Y, 2017: Photosynthetic and growth responses to ozone of Fagus crenata seedlings grown under different soil nutrient levels. Doctoral Dissertation in United Graduate School of Agricultural Science, Tokyo University of Agriculture and Technology, Fuchu Tokyo, Japan.

Kinose Y, Fukamachi Y, Okabe S, Hiroshima H, Watanabe M, Izuta T, 2017a: Nutrient supply to soil offsets the ozone-induced growth reduction in Fagus crenata seedlings. Trees 31, 259-272.

Kinose Y, Fukamachi Y, Okabe S, Hiroshima H, Watanabe M, Izuta T, 2017b: Photosynthetic responses to ozone of upper and lower canopy leaves of Fagus crenata Blume seedlings grown under different soil nutrient conditions. Environmental Pollution 223, 213-222.

Kitao M, Winkler JB, Löw M, Nunn AJ, Kuptz D, Häberle K-H, Reiter IM, Matyssek R, 2012: How closely does stem growth of adult beech (Fagus sylvatica) relate to net carbon gain under experimentally enhanced ozone stress? Environmental Pollution 166, 108-115.

Kohno Y, Matsumura H, Ishii T, Izuta T, 2005: Establishing critical levels of air pollutants for protecting East Asian vegetation - A challenge. In Plant responses to air pollution and global change (eds. by Omasa K, Nouchi I, De Kok LJ), Springer-Verlag, Tokyo, pp. 243-250.

Lee K-H, Jose S, 2003: Soil respiration, fine root production, and microbial biomass in cottonwood and loblolly pine plantations along a nitrogen fertilization gradient. Forest Ecology and Management 185, 263-273.

Leuschner C, Meier IC, Hertel D, 2006: On the niche breadth of Fagus sylvatica: soil nutrient status in 50 Central European beech stands on a broad range of bedrock types. Annals of Forest Science 63, 355-368.

Makita N, Hirano Y, Dannoura M, Kominami Y, Mizoguchi T, Ishii H, Kanazawa Y, 2009: Fine root morphological traits determine variation in root respiration of Quercus serrata. Tree Physiology 29, 579-585.

Matyssek R, Sandermann H, 2003: Impact of ozone on trees: an ecophysiological perspective. Progress in Botany 64, 349-404.

Matyssek R, Wieser G, Ceulemans R, Rennenberg H, Pretzsch K, Haberer K, Löw M, Nunn AJ, Werner H, Wipfler P, Oßwald W, Nikolova P, Hanke DE, Kraigher H, Tausz M, Bahnweg 
G, Kitao M, Dieler J, Sandermann H, Herbinger K, Grebenc T, Blumenröther M, Deckmyn G, Grams TEE, Heerdt C, Leuchner M, Fabian P, Häberle KH, 2010: Enhanced ozone strongly reduces carbon sink strength of adult beech (Fagus sylvatica) - resume from the free-air fumigation study at Kranzberg Forest. Environmental Pollution 158, 2527-2532.

Munoz C, Paulino L, Monreal C, Zagal E, 2010: Greenhouse gas $\left(\mathrm{CO}_{2}\right.$ and $\left.\mathrm{N}_{2} \mathrm{O}\right)$ emissions from soils: a review. Chilean Journal of Agricultural Research 70, 485-497.

Nakaji T, Izuta T, 2001: Effects of ozone and/or excess soil nitrogen on growth, needle gas exchange rates and Rubisco contents of Pinus densiflora seedlings. Water, Air and Soil Pollution 130, 971-976.

Nakaji T, Kobayashi T, Kuroha M, Omori K, Matsumoto Y, Yonekura T, Watanabe K, Utriainen J, Izuta T, 2004: Growth and nitrogen availability of red pine seedlings under high nitrogen load and elevated ozone. Water, Air and Soil Pollution, Focus 4, 277-287.

Nikolova PS, Andersen CP, Blaschke H, Matyssek R, Häberle $\mathrm{KH}$, 2010: Belowground effects of enhanced tropospheric ozone and drought in a beech/spruce forest (Fagus sylvatica L./Picea abies [L.] Karst). Environmental Pollution 158, 1071-1078.

Pregitzer KS, Burton AJ, King JS, Zak DR, 2008: Soil respiration, root biomass, and root turnover following long-term exposure of northern forests to elevated atmospheric $\mathrm{CO}_{2}$ and tropospheric $\mathrm{O}_{3}$. New Phytologist 180, 153-161.

Pregitzer KS, Loya W, Kubiske M, Zak D, 2006: Soil respiration in northern forests exposed to elevated atmospheric carbon dioxide and ozone. Oecologia 148, 503-516.

Pregitzer KS, Zak DR, Curtis PS, Kubiske ME, Teeri JA, Vogel CS, 1995: Atmospheric $\mathrm{CO}_{2}$, soil nitrogen and turnover of fine roots. New Phytologist 129, 579-585.

$\mathrm{R}$ Development Core Team, 2017: R: A Language and Environment for Statistical Computing. R Foundation for Statistical Computing, Vienna, pp. 3520. [online 15 January 2018] URL: http://www.R-project.org.

Rochette P, Ellert B, Gregorich EG, Desjardins RL, Pattey E, Lessard R, Johnson BG, 1997: Description of a dynamic closed chamber for measuring soil respiration and its comparison with other techniques Canadian Journal of Soil Science 77, 195-203.

Scagel CF, Andersen CP, 1997: Seasonal changes in root and soil respiration of ozone-exposed ponderosa pine (Pinus ponderosa) grown in different substrates. New Phytologist 136, 627-643.
Tingey DT, Johnson MG, Lee HE, Wise C, Waschmann R, Olszyk DM, Watrud LS, Donegan KK, 2006: Effects of elevated $\mathrm{CO}_{2}$ and $\mathrm{O}_{3}$ on soil respiration under ponderosa pine. Soil Biology \& Biochemistry 38, 1764-1778.

Wang B, Zha TS, Jia X, Wu B, Zhang YQ, Qin SG, 2014: Soil moisture modifies the response of soil respiration to temperature in a desert shrub ecosystem. Biogeosciences 11, 259-268.

Watanabe M, Hoshika Y, Inada N, Koike T, 2014: Canopy carbon budget of Siebold's beech (Fagus crenata) sapling under free air ozone exposure. Environmental Pollution 184, 682-689.

Watanabe M, Hoshika Y, Koike T, Izuta T, 2017a: Effects of ozone on Japanese trees. In Air Pollution Impacts on Plant in East Asia. (ed. by Izuta T). Springer Japan, Tokyo, pp. 73-100.

Watanabe M, Hoshika Y, Koike T, Izuta T, 2017b: Combined effects of ozone and other environmental factors on Japanese trees. In Air Pollution Impacts on Plant in East Asia. (ed. by Izuta T). Springer Japan, Tokyo, pp. 101-110.

Watanabe M, Yamaguchi M, Matsumura H, Kohno Y, Izuta T, 2008, Effects of ozone on growth and photosynthesis of Castanopsis sieboldii seedlings grown under different nitrogen loads. Journal of Agricultural Meteorology 64, 143-155.

Wittig VE, Ainsworth EA, Long SP, 2007: To what extent do current and projected increases in surface ozone affect photosynthesis and stomatal conductance of trees? A meta-analytic review of the last 3 decades of experiments. Plant, Cell \& Environment 30, 1150-1162.

Wittig VE, Ainsworth EA, Naidu SL, Karnosky DF, Long SP, 2009: Quantifying the impact of current and future tropospheric ozone on tree biomass, growth, physiology and biochemistry: a quantitative meta-analysis. Global Change Biology 15, 396-424.

Yamaguchi M, Watanabe M, Iwasaki M, Tabe C, Matsumura H, Kohno Y, Izuta T, 2007: Growth and photosynthetic responses of Fagus crenata seedlings to $\mathrm{O}_{3}$ under different nitrogen loads. Trees 21, 707-718.

Yamaguchi M, Watanabe M, Matsumura H, Kohno Y, Izuta T, 2011: Experimental studies on the effects of ozone on growth and photosynthetic activity of Japanese forest tree species. Asian Journal of Atmospheric Environment 5, 65-87.

Zhou L, Zhou X, Zhang B, Lu M, Luo Y, Liu L, Li B, 2014: Different responses of soil respiration and its components to nitrogen addition among biomes: a meta-analysis. Global Change Biology 20, 2332-2343. 